\title{
Arsenic induced genotoxic and histopathological changes in male Swiss albino mice, Mus musculus
}

\author{
A nimesh K. M ohapatra*, Deepika Rai and A nika Tyagi \\ Eco-toxicology Laboratory, Department of Zoology Regional Institute of Education (NCERT), Ajmer-305004 (Rajasthan), \\ INDIA \\ *Corresponding author. E-mail: akmrie01@yahoo.co.in
}

\begin{abstract}
The present study was carried out to investigate the effect of arsenic trioxide on the DNA and histomorphology of testis, liver and kidney of Swiss albino mice, Mus musculus. Oral administration of arsenic trioxide induced DNA damage in the testis, liver and kidney marked by light pink staining of nuclei after Feulgen's reaction with reduced fine chromatin. Simultaneously severe histological changes were noted like distortion of seminiferous tubules, disorganization of spermatogonia, spermatocytes and spermatids with cytoplasmic vacuolization and nuclear pycnosis in testis. There was almost disappearance of sinusoids due to disruption of hepatic plates, inflammatory cellular infiltration around central veins and cytoplasmic vacuolization in hepatocytes with large irregular nuclei in liver of treated mice. Disorganized glomeruli with distorted Bowman's capsules and mild to severe multifocal cloudy and hydropic degeneration with necrosis of tubules were observed in the kidney of treated mice. Inference drawn from the study indicated that arsenic induced both genotoxic histotoxic lesions.
\end{abstract}

Keywords: Arsenic, Genotoxic, Histopathological, Albino mice

\section{INTRODUCTION}

Heavy metals are natural components of the earth's crust and cannot be degraded or destroyed. They are recognized as strong biological poisons because of their persistent nature, toxicity and tendency to accumulate in organisms and undergo food chain amplification (Dinodia et al., 2000; Kamble and Muley, 2000). Anthropogenic activities have modified the global cycle of heavy metals and metalloid, including the non-toxic essential elements like $\mathrm{As}, \mathrm{Hg}, \mathrm{Cd}$, and $\mathrm{Pb}$. Industrial pollution of the environment with metal compounds is becoming a serious problem (Foulkes, 1990; Chougule et al., 2005; Babu et al., 2007). Among these metals, arsenic exhibits a complex metabolism and is possibly the most abundant pollutant as well as a potential human carcinogen (Roy and Saha, 2002). It is a naturally occurring ubiquitous element with metalloid properties and widely present in soil, rocks, sediments and metal ores in the form of oxides or sulfides or as a salt of iron, sodium, calcium, copper in the most part of the world (Aronson, 1994).

The effect of heavy metals on organisms is currently attracting widespread attention, particularly in studies related to pollution. With an early use of metals, there was little concern about environmental contamination. However, salts of the metals began to find their way into commercial and industrial applications and then it became evident that metallic salts possess certain biocidal properties. Though many metals play a vital role in the physiological processes of plants, animals and humans, yet excess concentration of metals is harmful (Gupta and Srivastava, 2006). Butcher (1946) asserted that pollution should be defined in terms of biological conditions rather than physico-chemical standards.

Many workers have reported cytopathological, hematological and biochemical abnormalities in various tissues of different animals after administration of sublethal doses of heavy metals (Gupta and Rajbanshi, 1982; Dalwani et al., 1985; Gill and Pant, 1987; McDowell, 1992; Gurer and Ercal, 2000; Srivastava and Kaushik, 2001; Shukla et al., 2002; Gupta and Srivastava, 2006). There is a dearth of studies on the toxic effect of heavy metals on mammalian tissues. Doreswamy et al., (2004) studied the effect of nickel on testicular histoarchitecture, DNA damage, and induction of apoptosis in testis and incidence of sperm head abnormalities in mice. Sharma et al. (1980) in guinea pig and Yang et al. (2006) in rats showed that administration of cadmium chloride caused degeneration of germinal epithelium accompanied by nuclear pycnosis followed by cytolysis and nuclear fragmentation in seminiferous tubules. Valverde et al. (2002) reported about lead induced genotoxic effect in the tissues of liver, kidney and lungs of mice.

Arsenic is semi-metallic in nature and widely present in the earth crust in the form of oxides or sulfides or as a salt of iron, sodium, calcium, copper etc. Arsenic and its compounds are well known for its toxicity and 
carcinogenicity. The study of environmental effects of arsenic is now very timely. Arsenic has become the focus of intense research globally because of its toxicity to humans and other organisms. Keeping the above facts in view, the present study was designed to observe the toxic effects of arsenic on mice.

\section{MATERIALS AND METHODS}

Healthy adult male mice (M us musculus) approximately 3 months old were used in the present investigation. Animals were housed in polypropylene cages and were kept in the laboratory under normal light and dark conditions. They were fed a standard commercial diet supplemented with vegetables and water was supplied through feeding bottles.

Two groups of animals - one control group of four mice and one treated group of eight mice were maintained separately for genotoxic and histopathological studies. The mice of treated group were fed orally a single does of arsenic trioxide dissolved in distilled water (30 mg per $\mathrm{kg}$ body weight) with the help of a micropipette. The mice of control group were given the same volume of distilled water used in the treated animals.

Animals from control and treated were scarified; dissected after 48 hours and 96 hours of treatment. For genotoxic examination testis, liver and kidney (small pieces) were quickly removed, then fixed in carnoy's fixative fluid. Following fixation, specimen's were dehydrated, embedded and then sectioned to 5 microns thickness. The sections were stained by Feulgen's method to demonstrate DNA (Gravin et al., 1976). For histopathological examinations, small pieces of liver, kidney and testes were fixed in Bouin's fixative fluid. Following fixation tissues were dehydrated, embedded and then sectioned at 5 microns thickness. The sections were stained with Ehrlich's Haematoxylin and Eosin (Adam and Caihak, 1964). Stained sections were then mounted on glass slides with DPX and covered with a cover slip. Genotoxic and histopathological changes were evaluated using light microscope and photographed using a digital camera.

\section{RESULTS}

Changes in testicular tissues: Microscopic description of the testis in the control group histological sections showed normally arranged seminiferous tubules (ST) with little connective tissue (CT) in the interstitial spaces containing Leydig cells (the cells responsible for testosterone production in the testes) (Figs.1,2). Spermatogonia, spermatocytes, and spermatids were regularly arranged with, spermatozoa in the lumen of seminiferous tubules (Fig.2). Examination of sections of testis of treated mice showed that testis had lost its characteristic architecture compared with the control group. There is marked distortion of seminiferous tubules with almost complete disintegration of connective tissue between them (Fig.5). In case of 48 hours post treatment, disorganization of the spermatogonia to a small extent has been noticed. They have detached from basal lamina of seminiferous tubules causing their distortion and consequent loss of their lumen. Due to desquamation of germ cells, numerous small spaces have appeared inside majority of seminiferous tubules. In the interstitium considerable engorgement of the interstitial blood vessels are noticed (Fig.3-6). Histological examination of 96 hour Post-treatment reveals that the characteristic organized architecture of the cells in the seminiferous tubules got disturbed more than that observed in the 48 hours posttreatment mice. Cells in seminiferous tubules showed nuclear fragmentation, nuclear pycnosis and cytoplasmic disintegration in the varied germ cells. The cytoplasm of spermatogonia, spermatocytes appear paler due to vacuolization (Figs.5,6). Sertoli cells have lost their integrity and hence can be identified with difficulty. Interstitial cells show marked reduction in size with nuclear pycnosis. There is a pronounced reduction in sperm amount in the lumen of seminiferous tubules and many tubules are totally devoid of sperms (Figs.3-6). Nuclei of spermatogonia, spermatocytes, spermatids, sperm, sertoli cells and Leydig cells stained dark pink after Feulgen's reaction in the testis of control mice. Light pink staining of the nuclei of these cells after Feulgen's reaction in treated mice indicates that the DNA has probably degraded due to arsenic toxicity (Figs.9-12).

Changes in liver tissue: Examination of liver sections of $\mathrm{As}_{2} \mathrm{O}_{3}$ treated mice showed that the liver had lost its characteristic architecture compared with the control group (Figs.13-18). In the Liver sections of treated mice, there is almost disappearance of sinusoids due to disruption of hepatic plates. The cytoplasms of the hepatocytes are characterized by coarse, pink, darkly stained granules and few vacuoles in 48 hours posttreatment sections. There is increase in cytoplasmic vacuolization in 96 hours post-treatment sections (Fig.18). Inflammatory cellular infiltration was abundant around central vein which is more intense in 96 hours post-treatment liver sections (Fig.18). The nuclei of hepatocytes in treated mice appeared larger and more irregular in shape with very little peripheral condensed chromatin (Fig.16). Meanwhile, clumped chromatin was also observed in many of the hepatocytes and some nuclei appeared pycnotic. The nucleoplasm of many cells showed continuity with the cytoplasm due to loss of nuclear membranes. In many places, hepatic lobules have merged due to disintegration of capsular tissues. Light pink staining of the nuclei of hepatocytes of treated mice in comparison to control mice after Feulgen's reaction indicates DNA damage. There is a reduction in fine chromatin in treated group than the control group 
(Figs.19-24).

Changes in renal tissues: The normal histological structures of the kidney having normal arrangement of cortical and medullary elements were observed in the section of control group mice (Figs.25, 26). The kidney of treated group mice showed significant histopathological abnormalities like disorganized glomeruli with distorted Bowman's capsule, loss of cellular integrity of tubular cells, multifocal cloudy and cellular infiltrations (Figs.27-30). The tubular cells appeared swollen with cytoplasmic vacuolization and coarse pink cytoplasmic granules especially in the cells of the proximal and distal convoluted tubules. Lumens of these tubules were obliterated or highly reduced (Fig.30). Nuclei of majority of the tubular cells showed clumped chromatin and pycnosis. Arsenic induced DNA damage was observed in the cells of proximal tubule, limbs of Henle's loop, distal tubule, collecting duct and renal corpuscles in the treated mice as evident from light pink staining of nuclei after Feulgen's reaction in comparison to control mice (Figs.31-36).

\section{DISCUSSION}

Heavy metals have been recognized as strong biological poisons because of their persistent nature, toxicity, tendency to accumulate in organisms and undergo food chain amplification (Kamble and Muley, 2000; Dinodia et al., 2002). The toxic effects of heavy metals are due to disturbances of the normal gene expression in the tissues. Few researchers have shown genotoxic effects of heavy metals. Valverde et al. (2002) have shown inhalation of lead induced DNA damage in tissues of lungs, liver, kidney and brain in mice. Doreswamy et al. (2004) and Stinson et al. (1992) have reported that administration of Nickel caused significant degree of DNA damage in testis of mice and rat liver respectively. In the present study, arsenic induced significant DNA damage in tissues of testis, liver and kidney. Our data are consistent with earlier reports on arsenic trioxide-induced DNA damage (Saleha et al., 2001; Fengyuan et al., 2005; Patlolla and Tchounwou, 2005). DNA containing particles (Chromatin) in the nuclei of spermatogonia, spematocytes, and spermatids in testis, in the nuclei of hepatocytes in liver and in the cells of renal tubules of normal mice demonstrated by Feulgen's reaction as red densely stained particles in the nucleoplasm. These particles are either distributed equally in the nucleoplasm or restricted to the peripheral rims of the nuclei. Reduction in DNA containing particles and lighter pink staining of the nuclei of spermatogonia, spermatocytes and spermatids in testis, nuclei of hepatocytes in liver and tubular cells of kidney of arsenic treated mice in comparison to control group mice after Feulgen's reaction clearly indicates DNA damage in the present study. It is further supported by reduction in fine chromatin in these cells of treated group. Arsenic, not only damage DNA in the cells of testis, liver and kidney but also produced genotoxic effects in other organs. Saleha et al. (2001) showed a significant increase in comet tail length in blood cells of arsenic treated mice which clearly gives evidence that arsenic trioxide cause DNA damage effectively. Patlolla and Tchounwou (2005) investigated the genotoxic potential of arsenic trioxide in bone-marrow cells of rats. They observed that arsenic trioxide exposure significantly increased the number of structural chromosomal aberrations, the frequency of micro-nucleated cells and decreased the mitotic index in treated group when compared with the control group. Fengyuan et al. (2005) reported that arsenic causes pathological changes through oxidative DNA damage in the brain tissue of mice. In conclusion, in the present study arsenic exposure produced genotoxic effect this was apparently associated with DNA damage in testis, liver and kidney. The genotoxic effects can be interpreted as a specific effect on spermatids and spermatozoa (i.e. decreased amount) which can play a significant role in the development of male infertility.

The results presented in this study clearly demonstrate that exposure of adult mice to $\mathrm{As}_{2} \mathrm{O}_{3}$ had adverse effect on the histoarchitecture of testis, liver and kidney. The histopathological alterations induced in the testis of $\mathrm{As}_{2} \mathrm{O}_{3}$ treated mice involves distortion of seminiferous tubules with partial to almost complete disintegration of connective tissue between them; loss of lumen in the tubules due to desquamation and distortion of germinal epithelial and other tubular cells and cytoplasmic vacuolization in spermatogonia and spermatocytes which are more pronounced in 96 hours post-treatment mice. These results are in agreement with the data published by Parizek (1960), Mason et al. (1964), Favino et al. (1966), Saksena and Lau (1979), Sharma et al. (1980), Elbetieha and Al-hamood (1997), Bataineh et al. (1998), Mayyas et al. (2005) and Yang et al. (2006) for many other heavy metals. In the present study a significant reduction in sperm amount (some seminiferous tubules are totally devoid of sperm) was observed. The sertoli cells (supporting cells) were also destroyed in treated mice. This reduction in sperm amount could be the result of reduced spermatogenesis due to DNA damage in germ cells, histological abnormalities and nonfunctioning of sertoli cells. These findings are consistent with earlier reports of Kwon et al., 1997; Bench et al., 1999 and Tbeileh et al., 2007. They have shown the heavy metal cadmium's detrimental effect on histology of testis resulting in significant decreased sperm production. Fiorini et al. (2004) reported that testicular toxicants such as cadmium reduce or redistribute specific functional surface proteins on the sertoli cell membrane that are necessary for the development and maintenance of spermatogenesis and 


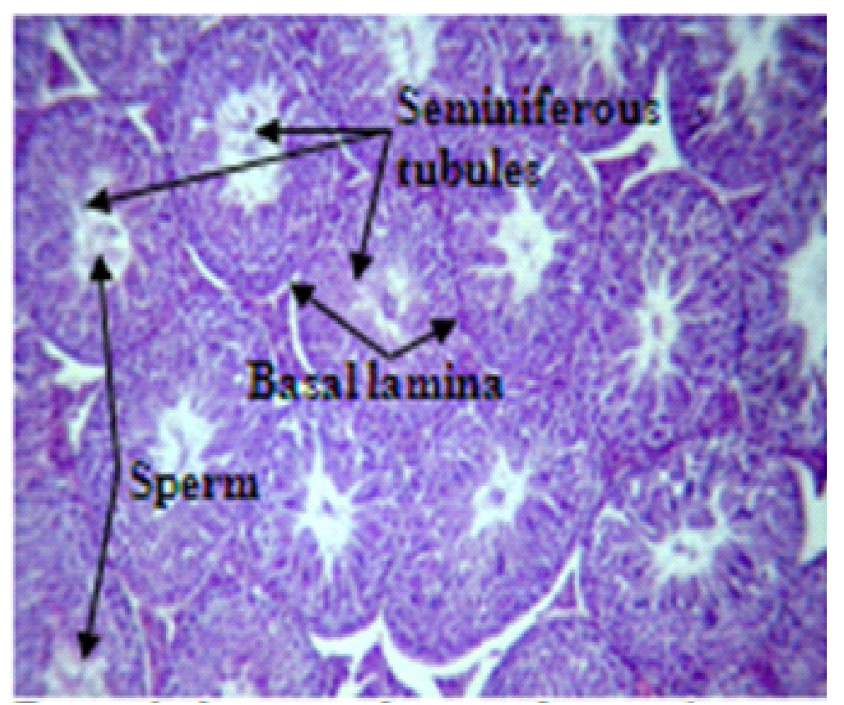

Fig. 1. Section of testis of control mice showing normal histoar citecture containing seminifer ous tubuls (SF) covered by basal lamina (BL).

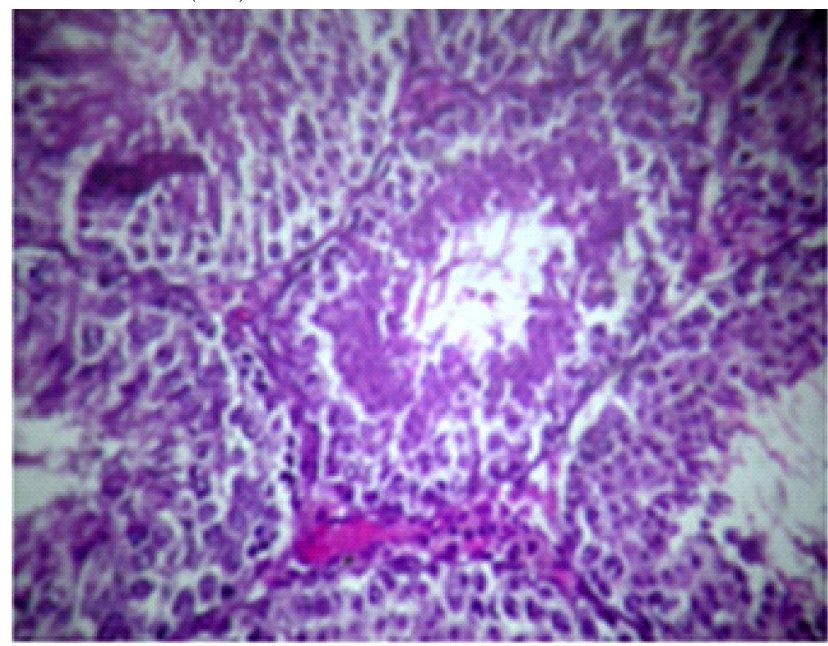

Fig. 3. Section of testis of 48 hours post-treatment treated mice showing disorganization of cells in SF s.

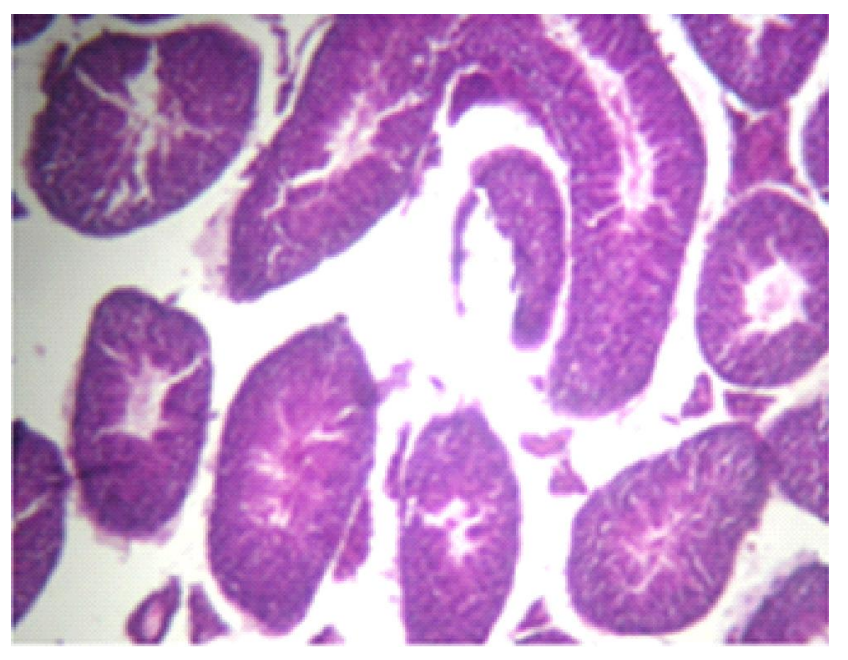

Fig. 5. Section of testis of 96 hours post-treatment treated mice showing distoration of SFs and disintegration of tissues in between SFs.

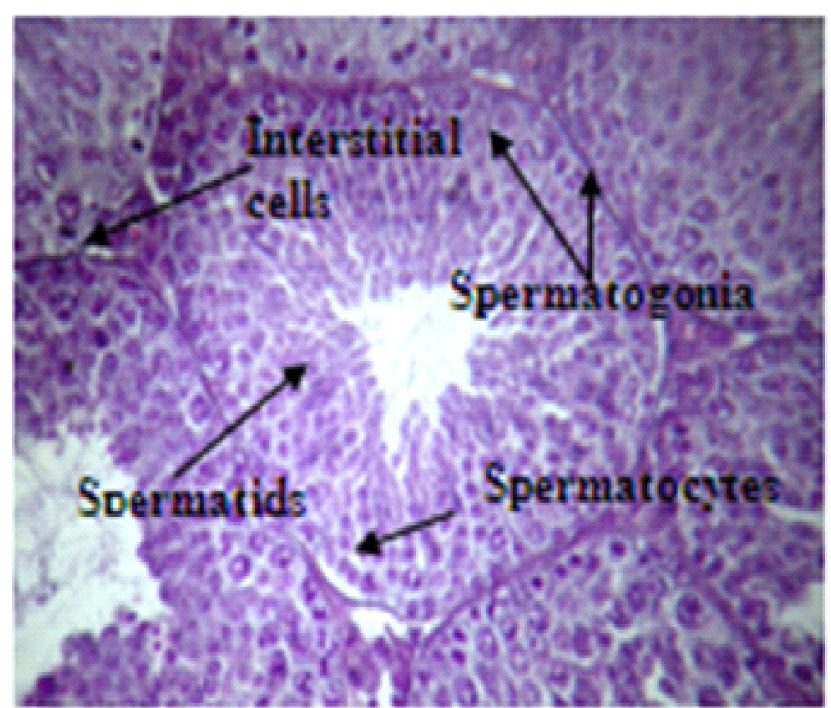

Fig. 2. Section of testis of control mice showing spermatognia (SG), spermatocytes (SC), spermatids (ST), sperms (S), and interstitial cells (IC).

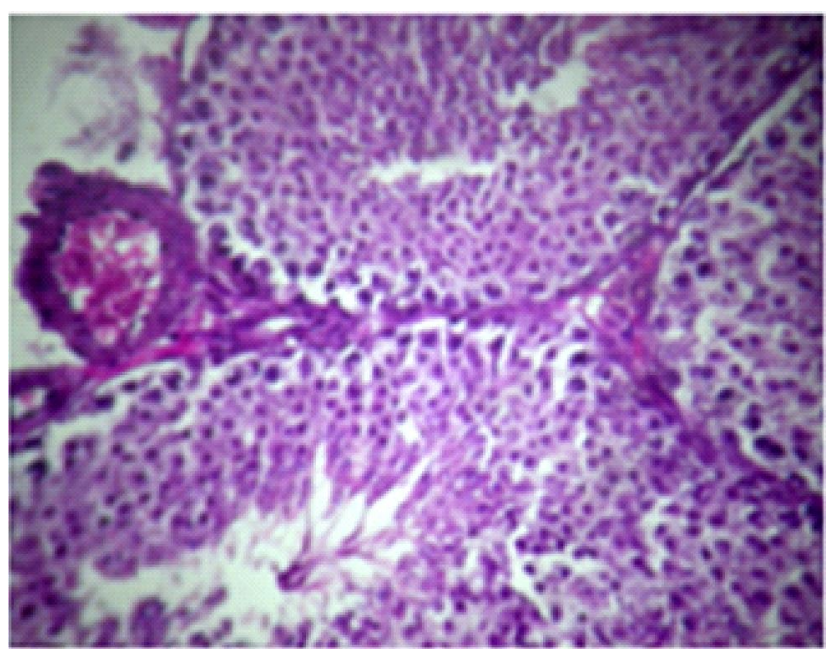

Fig. 4. Section of testis of 48 hours post-treatment treated mice showing necrosis of tissues in the inter stitial spaces.

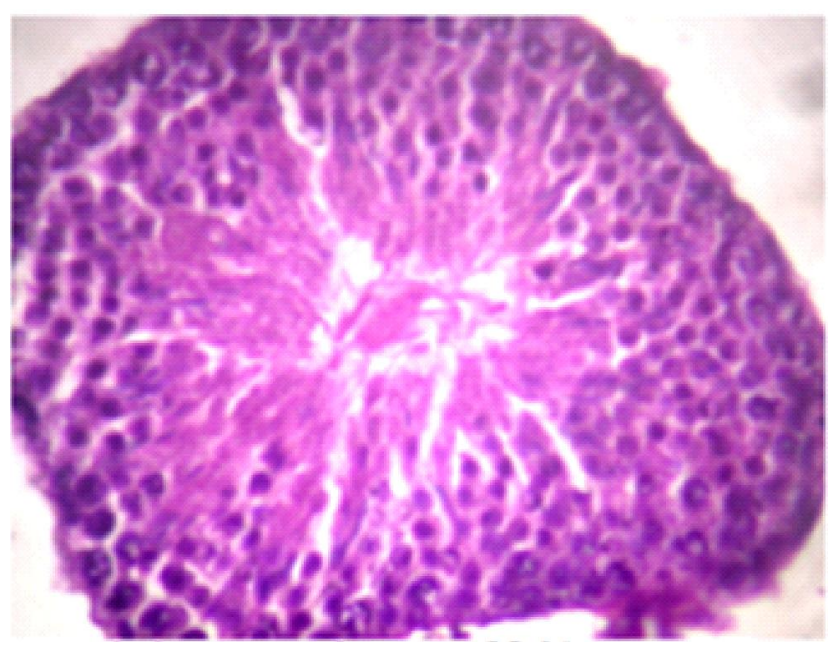

Fig. 6. Section of testis of 96 hours post-treatment treated mice showing cytoplasmic vacuolization of cells in SF s. 


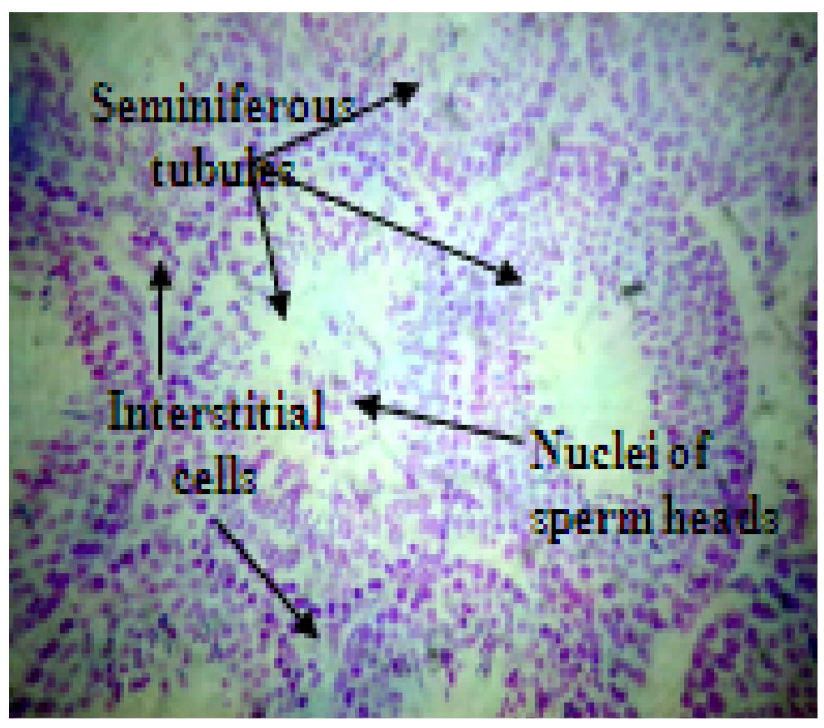

Fig. 7. Section of testis of control mice showing DNA content in the cells of seminiferous tubule (SF) after F eulgen's reaction.

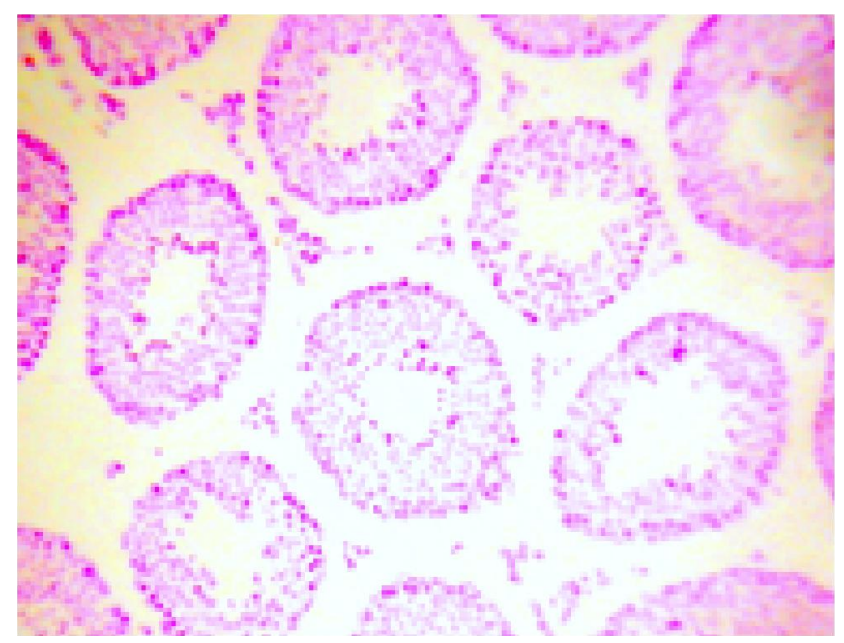

Fig. 9. Section of testis of 48 hours post treatment mice showing DNA content in the cells of seminiferous tubuls (SF 5) after F eulgen's reaction.

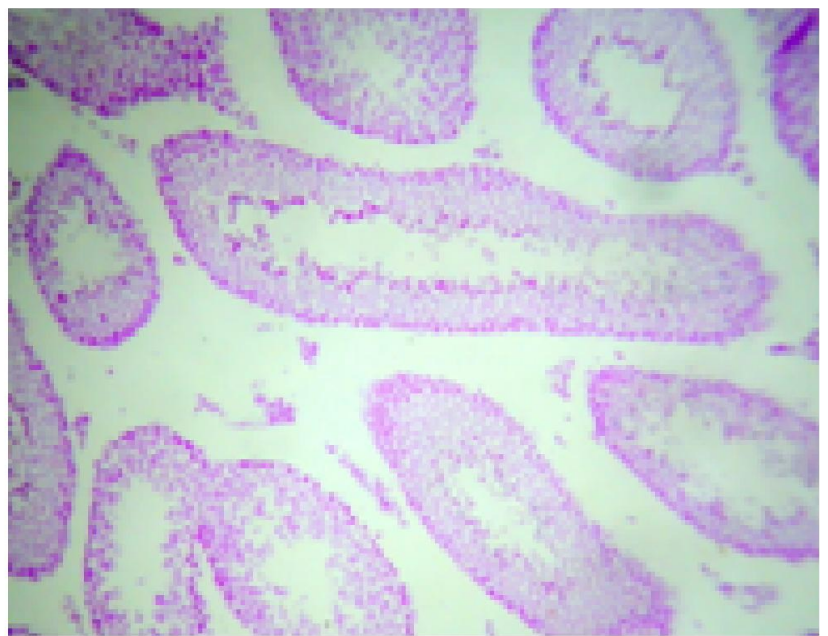

Fig. 11. Section of testis of 96 hours post treatmentmice showing DNA content in the cells of seminiferous tubules (SF 5 ) after F eul gen's reaction.

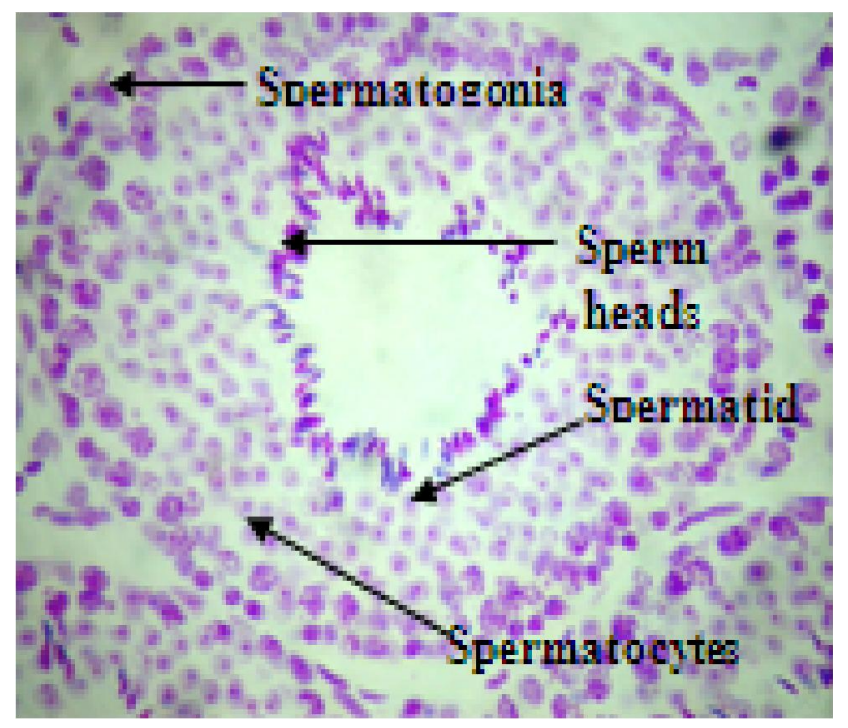

Fig. 8. Section of testis of control mice showing D NA content in the $\mathrm{SG}_{5}, \mathrm{SG}_{5}, \mathrm{ST}_{5}$, and in sperms after F eulgen's reaction.

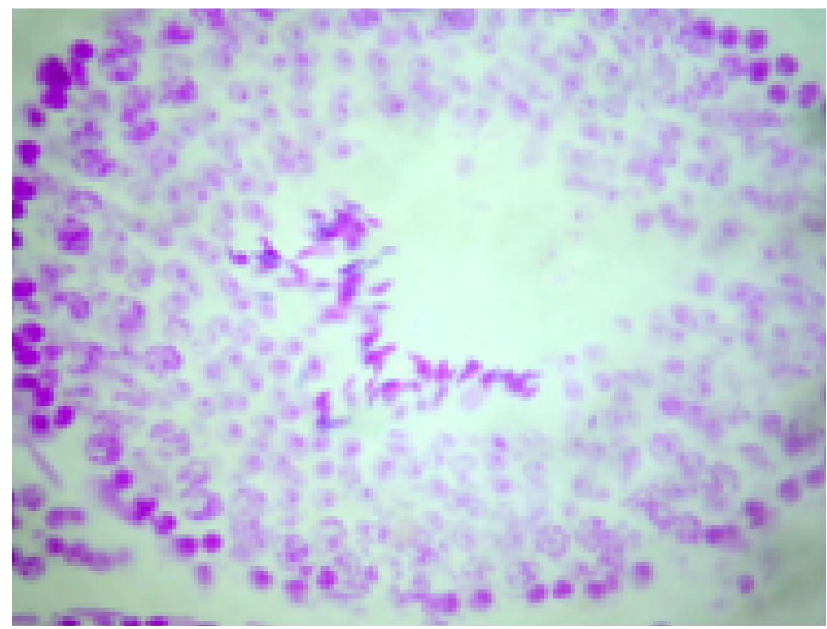

Fig. 10. Section of testis of 48 hours post treatment mice showing D NA content in the $\mathrm{SG}_{5^{\prime}} \mathrm{SG}_{5^{\prime}} \mathrm{ST}_{5^{\prime}}$ and in sperms after F eulgen's reaction.

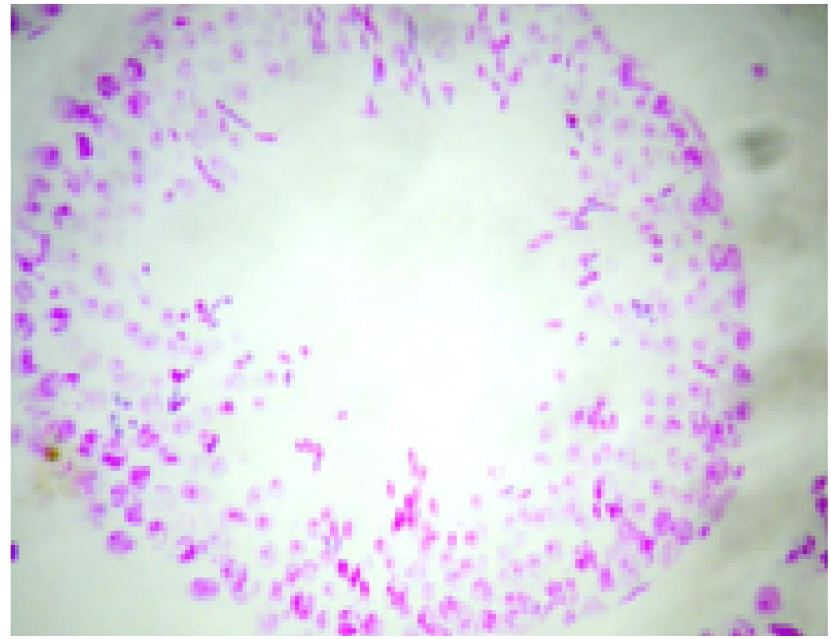

Fig. 12. Section of testis of 96 hours post treatment mice showing DNA content in the $\mathrm{SG}_{5}, \mathrm{SG}_{5}, \mathrm{ST}_{5}$, and in sperms after F eulgen's reaction. 


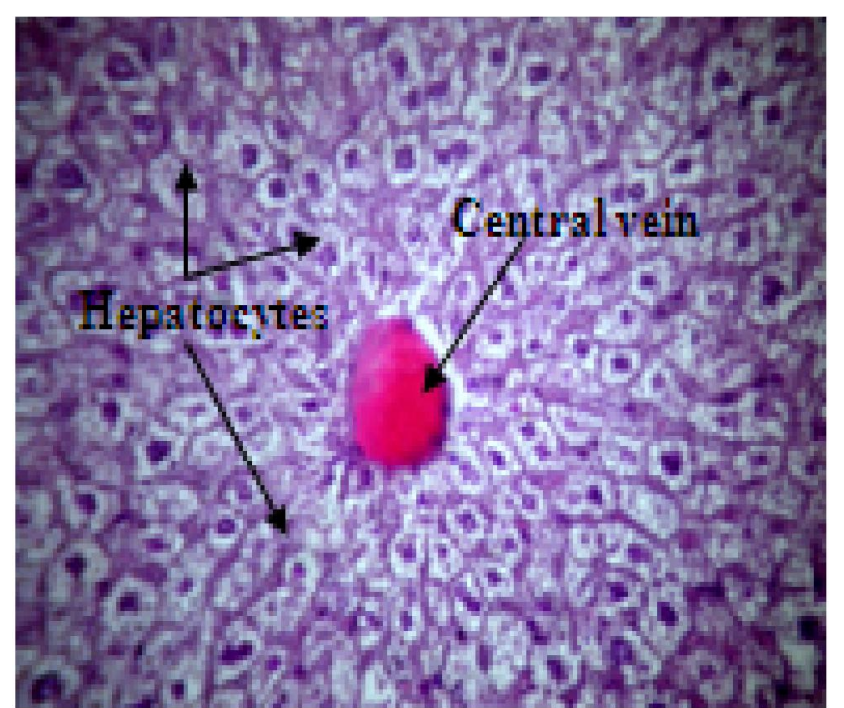

Fig. 13. Section of liver of control mice showing normal histoarcitecture.

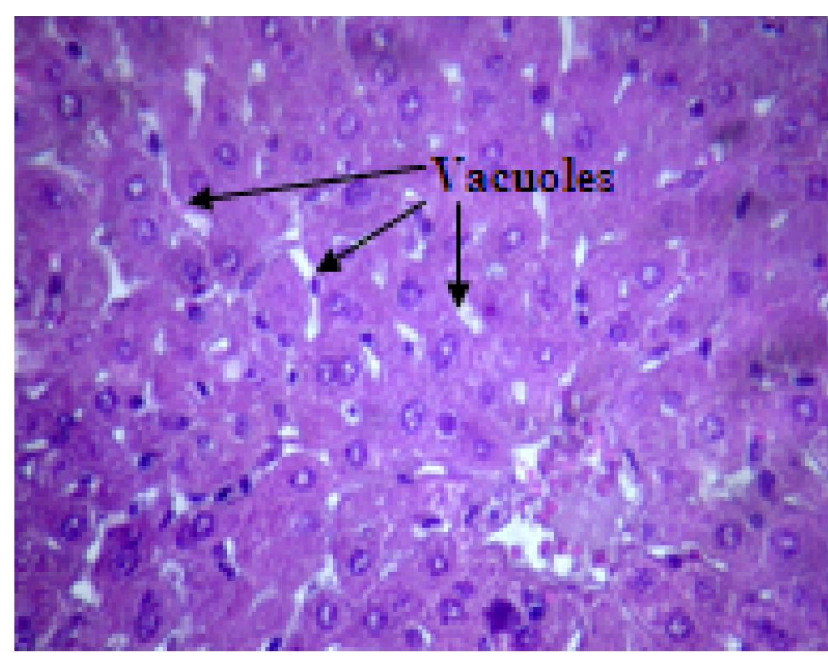

Fig. 15. Section of 48 hours post-treatment treated mice showing disintegration and cytolasmic vascuolization's in cells.

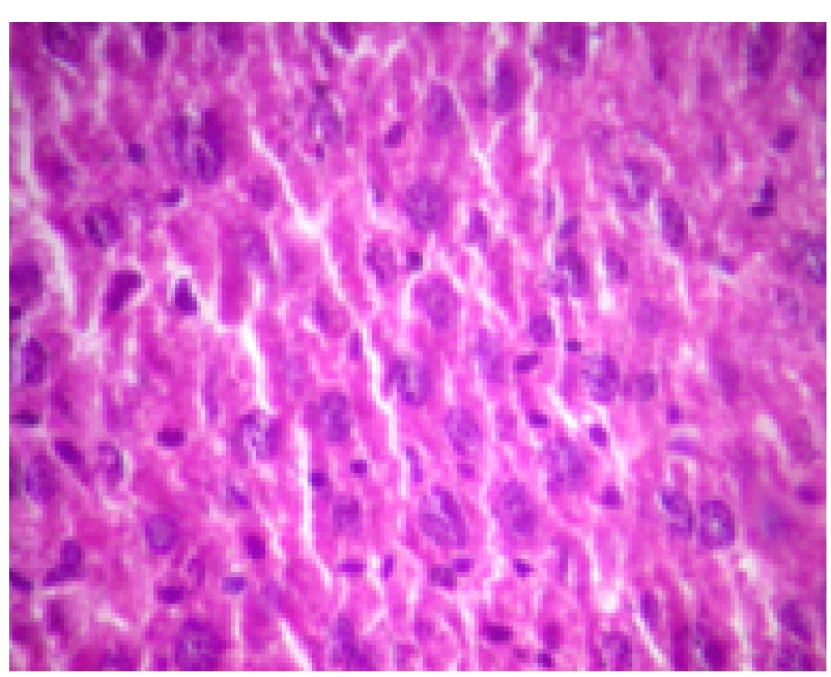

Fig. 17. Section of liver 96 hours post-treatment treated mice showing disintegration and cytolasmic vascuolization's of cells.

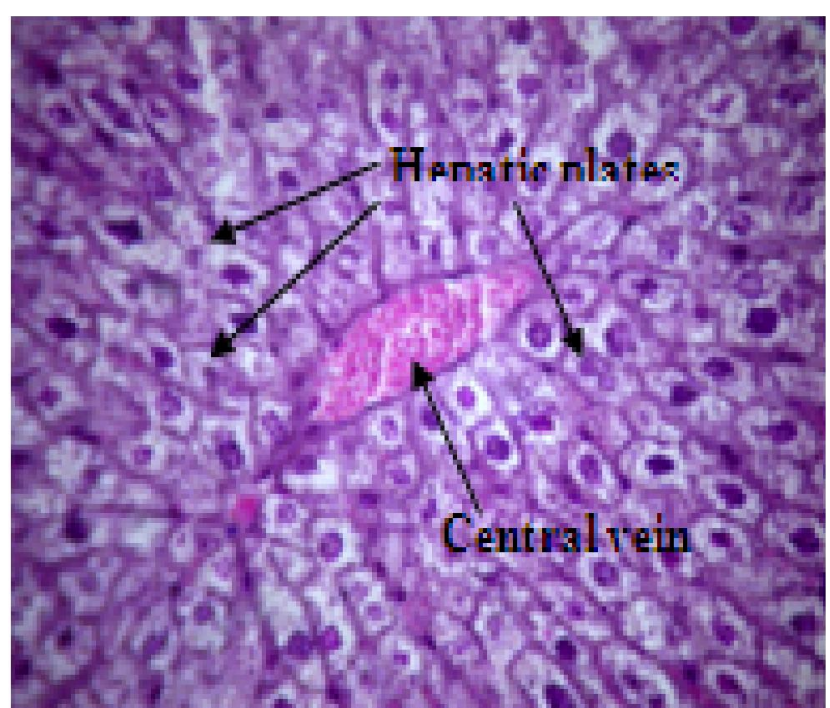

Fig. 14. Section of liver of control mice showing central vein and hepatocytes.

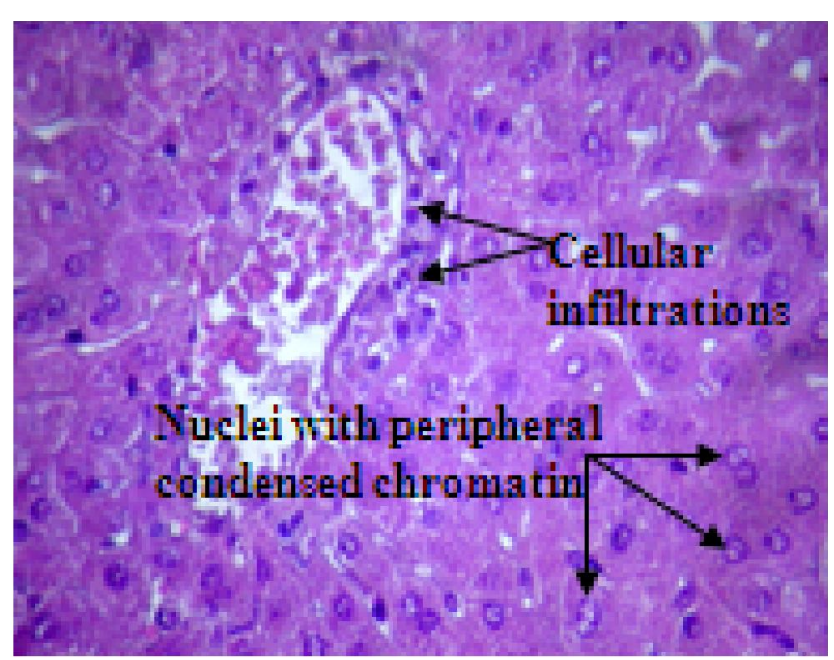

Fig. 16. Section of 48 hours post-treatment treated mice showing cellular infilterations and nuclei containing perpheral condensed chromatin.

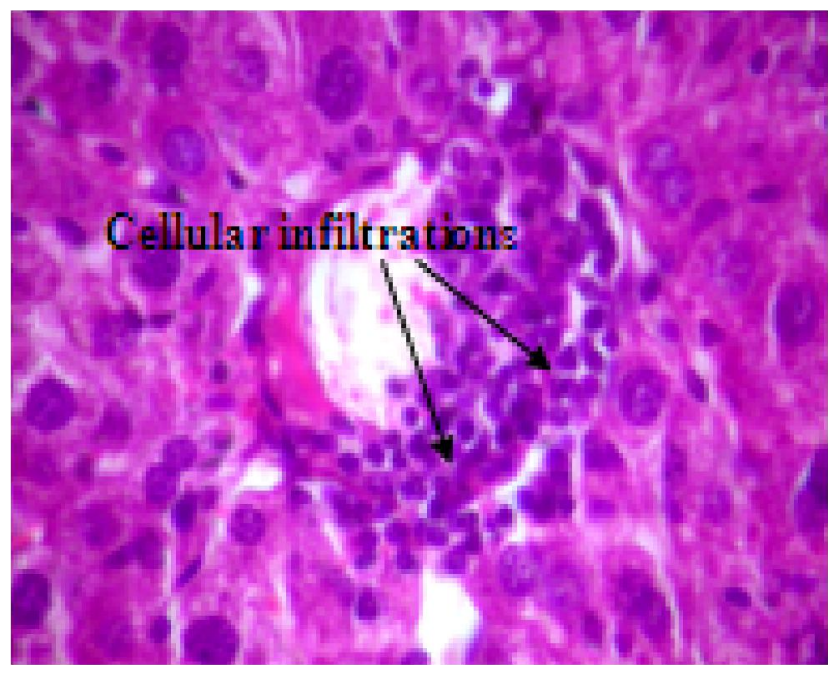

Fig. 18. Section of liver 96 hours post-treatment liver of treated mice showing fibrosis and celllar infilteration and necrosis. 


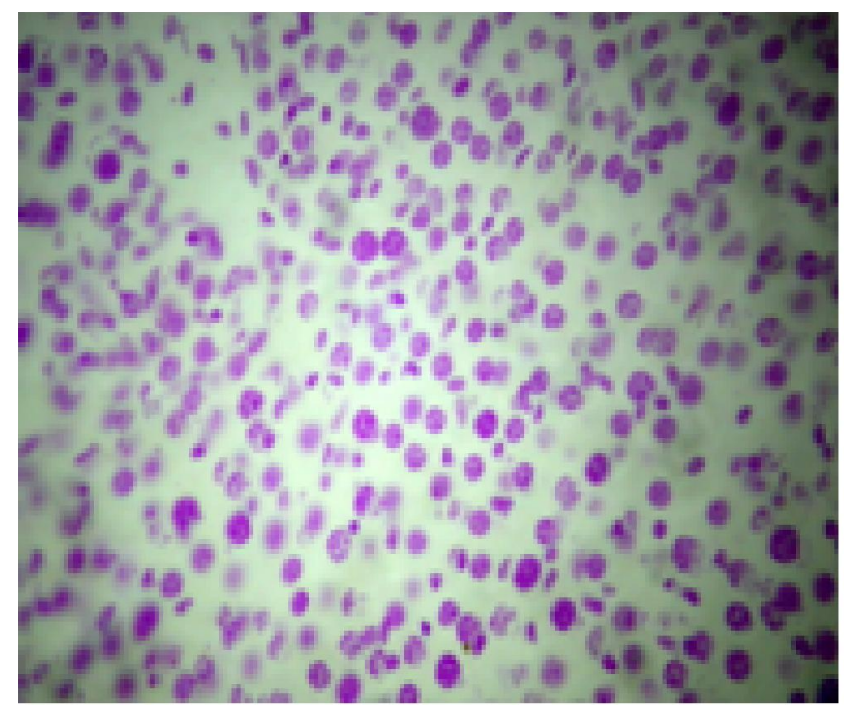

Fig. 19. Section of liver of control mice showing D NA in nuclei of hepatocytes after F eulgen's reaction.

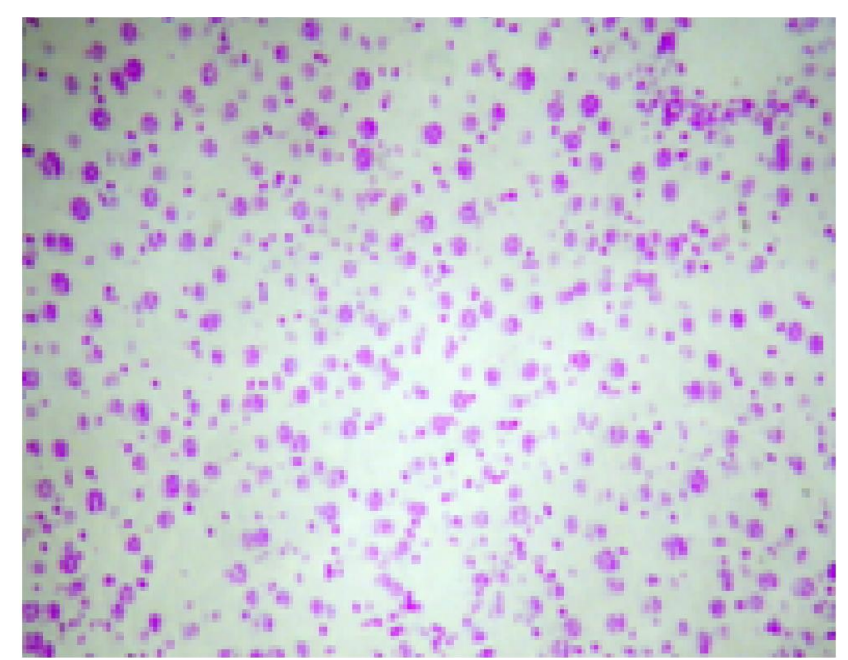

Fig. 21. Section of liver of 48 hours post treatmentmice showing DNA in nuclei of hepatocytes after F eulgen's reaction.

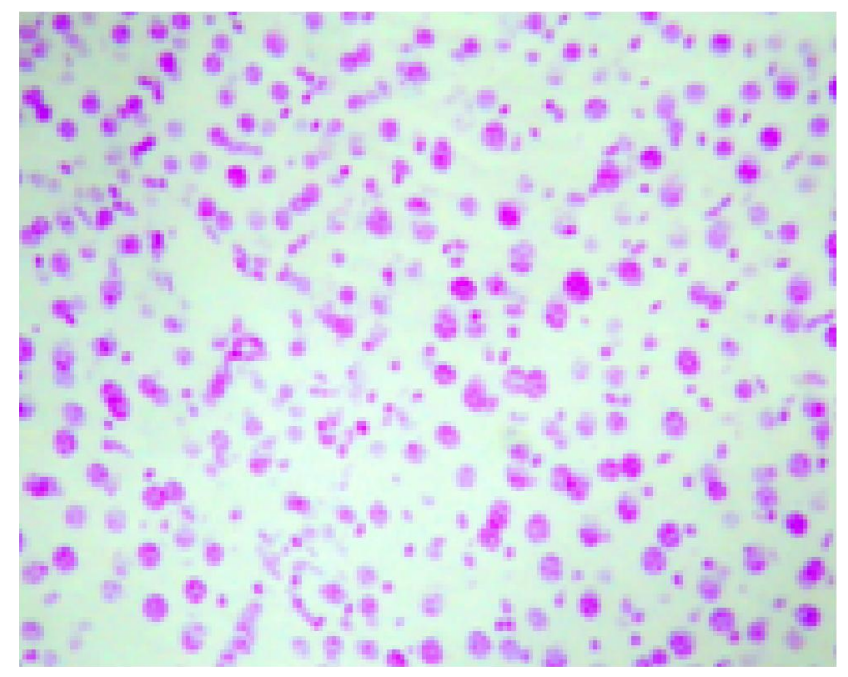

Fig. 23. Section of liver of 96 hours post treatmentmice showing DNA in nuclei of hepatocytes after F eulgen's reaction.

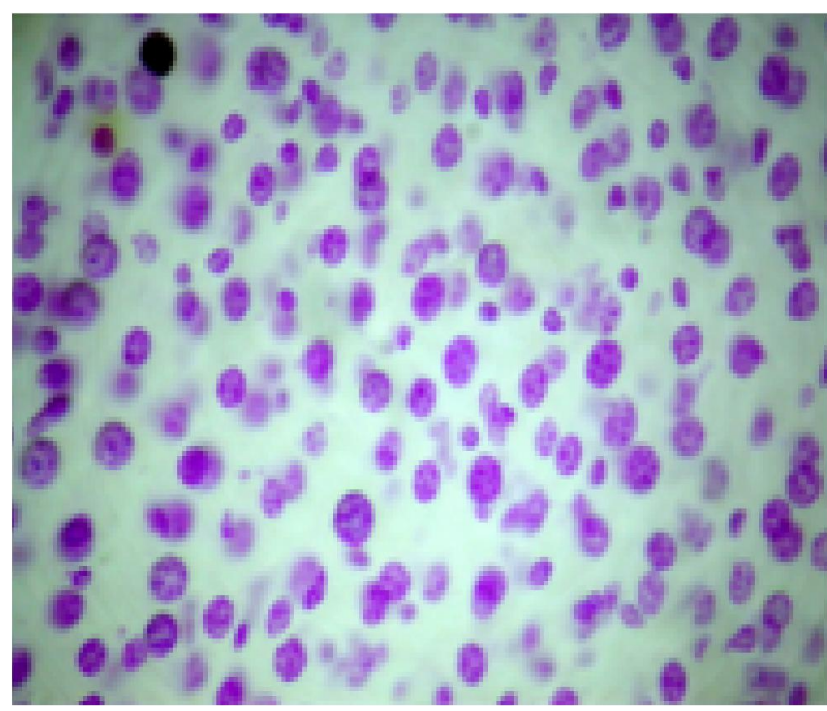

Fig. 20. Section of liver of control mice showing D NA in nuclei of hepatocytes after Feulgen's reaction.

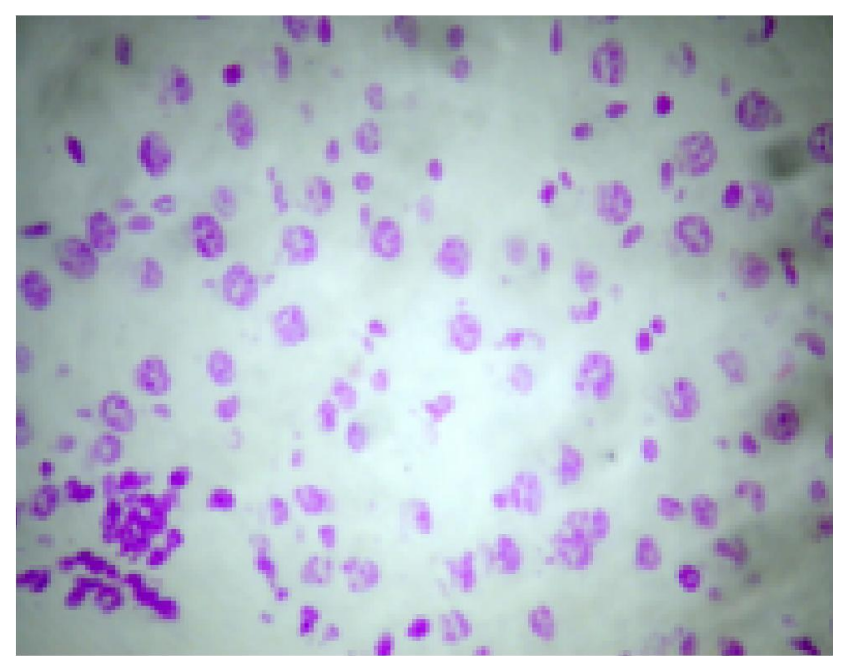

F ig. 22. Section of liver of 48 hours post treatment mice showing DNA in nuclei of hepatocytes after F eulgen's reaction.

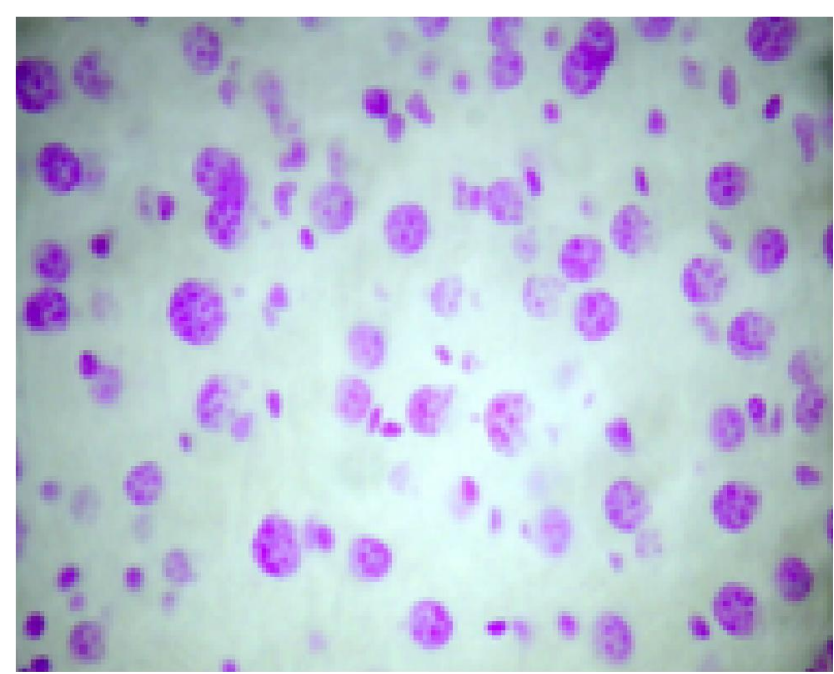

Fig. 24. Section of liver of 96 hours post treatment mice showing DNA in nuclei of hepatocytes after F eulgen's reaction. 


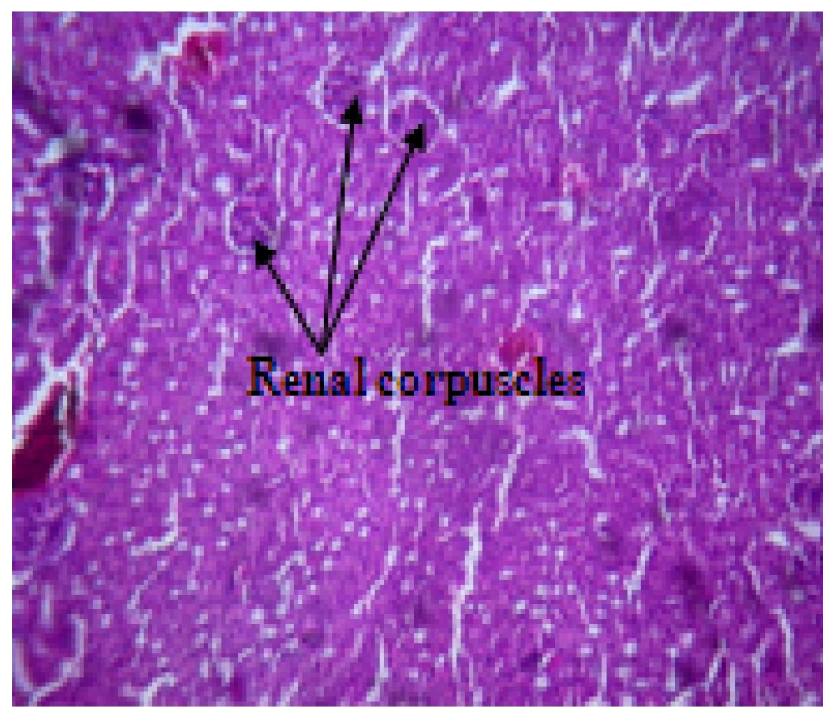

Fig. 25. Section of kidney of control mice showing normal histoarchitecture.

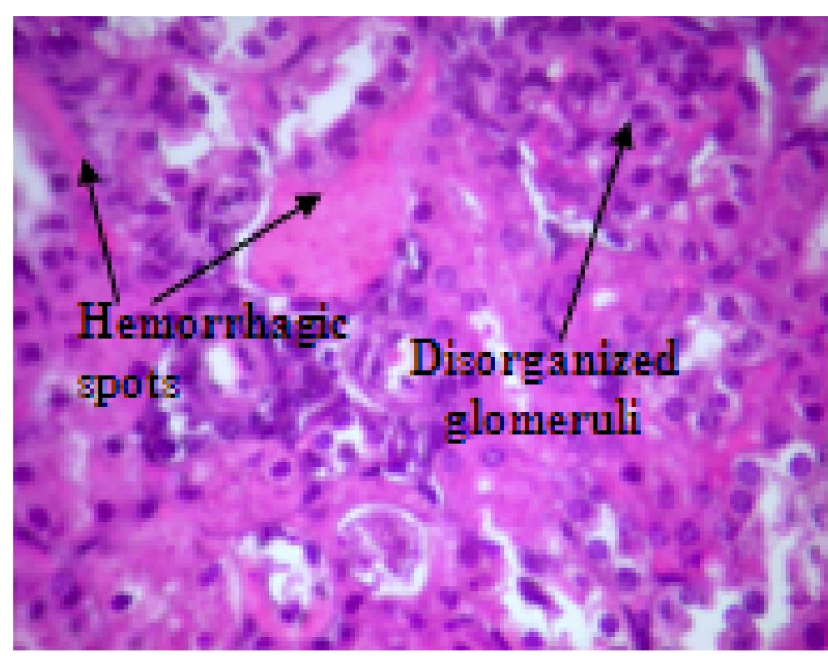

Fig. 27. Section of 48 hours post - treatment kidney of treated mice showing disorganized glomeruli and cellular infiltration.

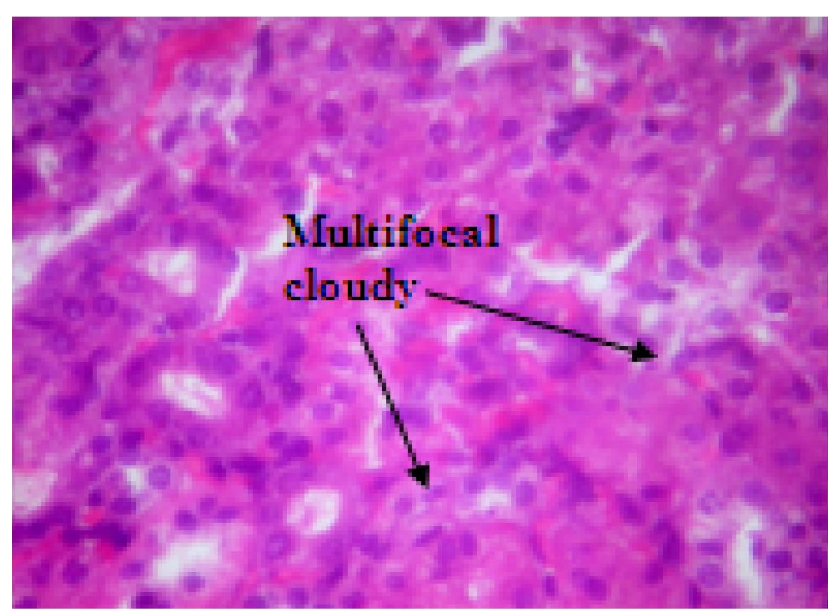

Fig. 29. Section of 96 hours post - treatment kidney of treated mice showing multifocal cloudy and cytoplasmic vacuolizations of cells.

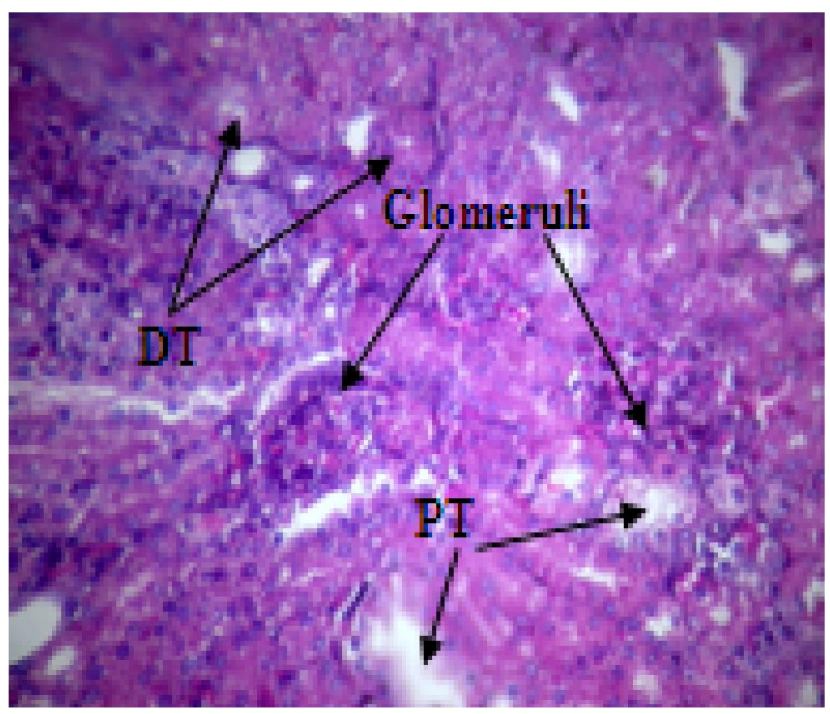

Fig. 26. Section of kidney of control mice showing normal glomerules and proximal tubule (PT) and distal tubule (DT).

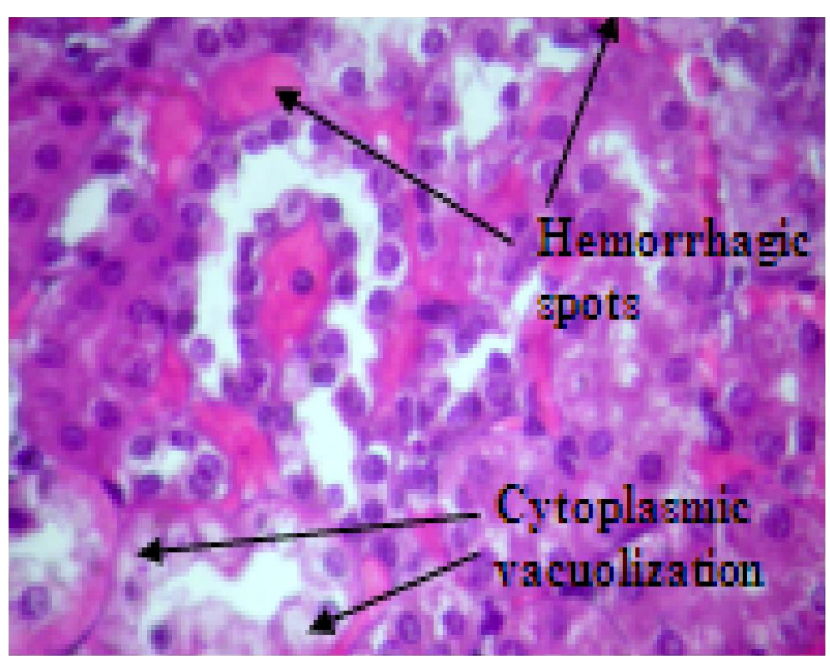

Fig. 28. Section of 48 hours post - treatment kidney of treated mice showing lesions of cortical tissues with hemorrhagic spots.

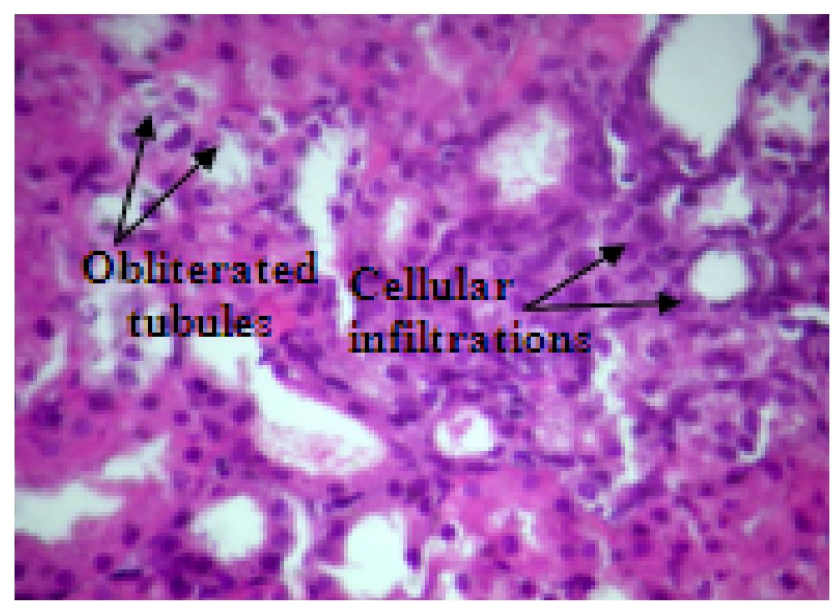

Fig. 30. Section of 96 hours post - tratment kidney of treated mice showing cellular infiltrations, obliterated tubules and hemorrhagic spots. 


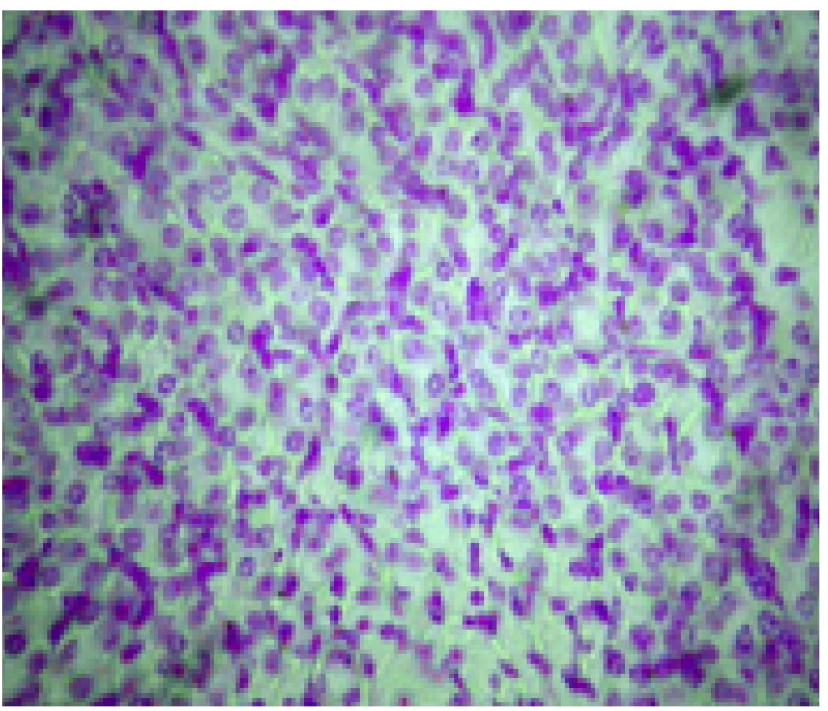

Fig. 31. Section of kidney of control mice showing DNA in nuclei of tubular cells after F eulgen's reaction.

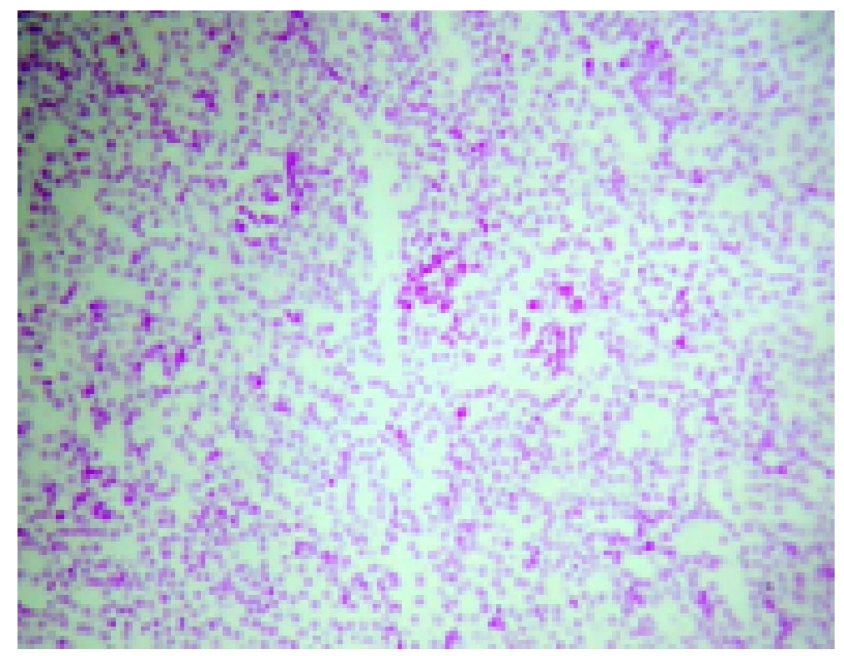

Fig. 33. Section of kidney of 48 hours post treatment mice showing DNA in nuclei of tubular cells after F eulgen's reaction.

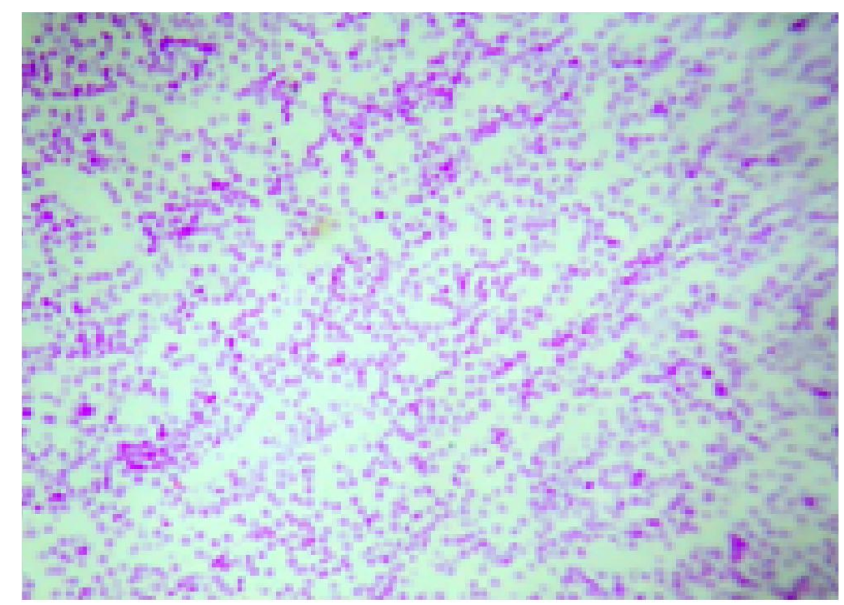

Fig. 35. Section of kidney of 96 hours post - tratment mice showing D NA in nuclei of tubular cells after F eulgen's reaction.

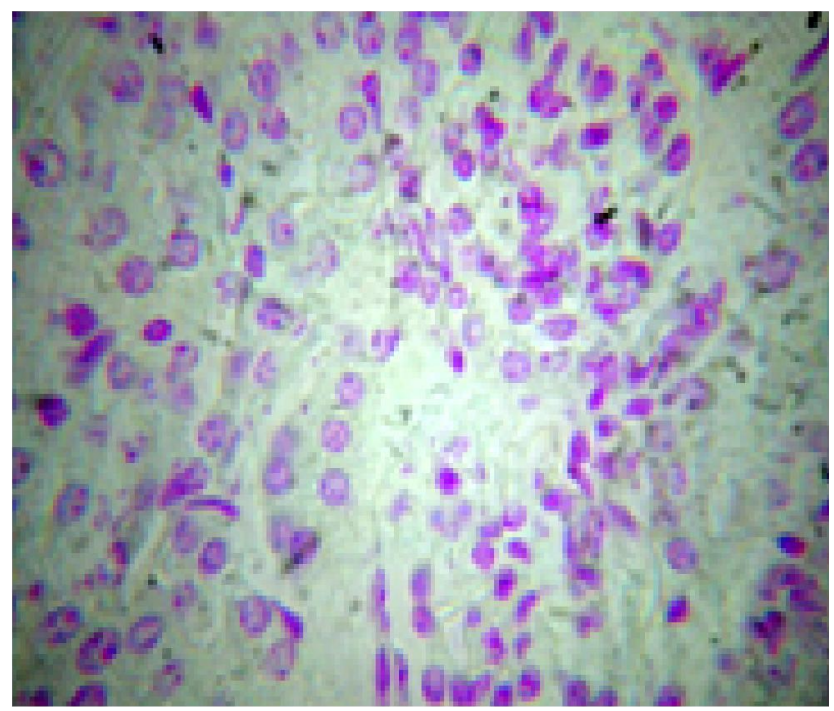

Fig. 32. Section of kidney of control mice showing DNA in nuclei of tubular cells after $F$ eulgen's reaction.

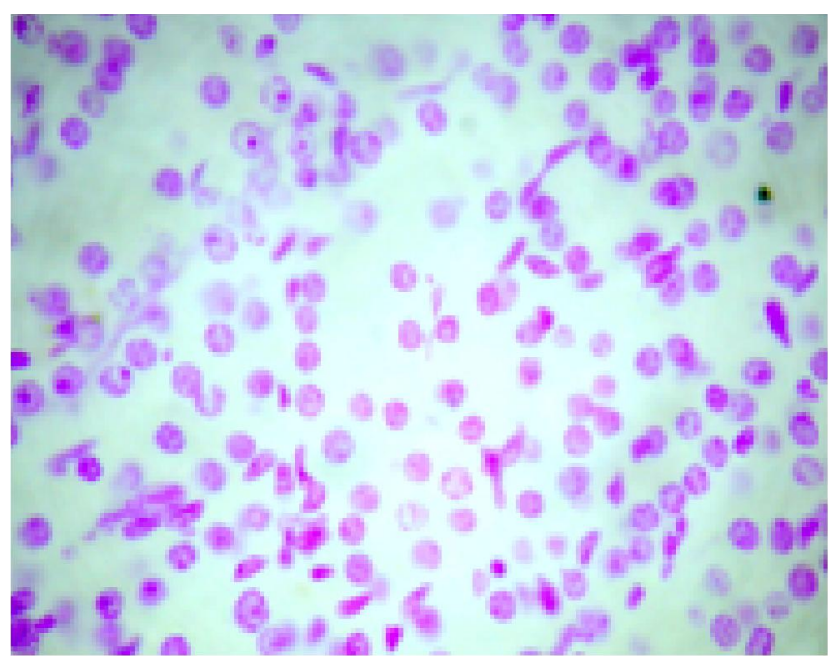

Fig. 34. Section of kidney of 48 hours post treatment mice showing DNA in nuclei of tubular cells after F eulgen's reaction.

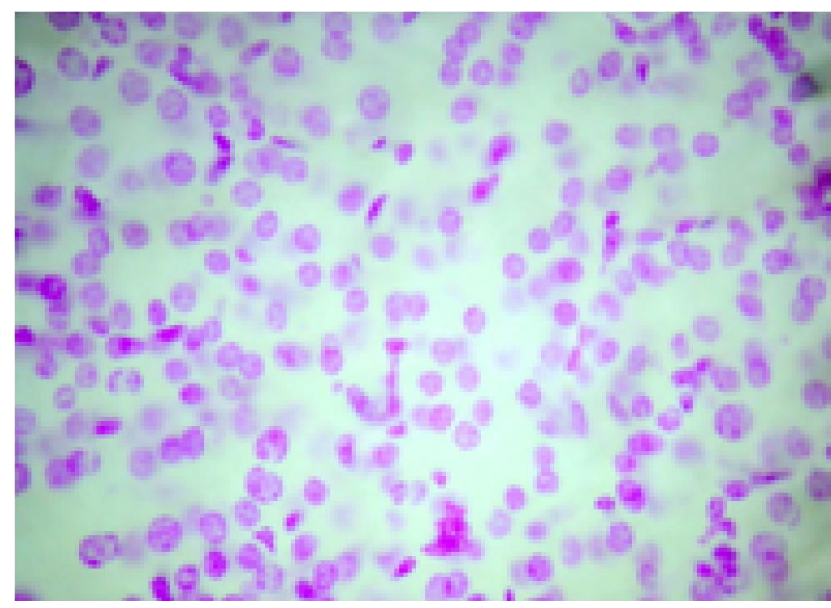

Fig. 36. Section of kidney of 96 hours post - tratment mice showing DNA in nuclei of tubular cells after Feulgen's reaction. 
these alterations may lead to reduction in sperm amount and sterility in males.

There have been very few reports of histopathological changes, occurring in liver from exposure to heavy metals in different group of vertebrates. Application of the arsenic under investigation induced many histopathological alterations in the hepatic tissues. In the present study, the progressive degenerative changes observed in the histology of liver of mice exposed to arsenic indicates the severity of metal stress. Such changes were time dependent. Application of the arsenic under investigation induced many histopathological alterations in the hepatic tissues like disappearance of sinusoids due to disruption of hepatic plates, cytoplasmic vacuolization, irregular nuclei with clumped chromatin and inflammatory cellular infiltration around central veins. Similar results have also been reported by Chishti and Rotkiewicz (1993) in cockerels, Karmakar et al. (2000) in mice on exposure to cadmium and Soni and Gupta (2006) in Heteropneustis fossilis on exposure to mercuric chloride. Zhang and Wang (1984) suggested that the cytoplasmic vacuolization is mainly a consequence of considerable disturbance in lipid inclusions and fat metabolism occurring during pathological changes. Robbins and Angell (1976) suggested a mechanism for the cytoplasmic vacuolation as one of the important responses to all forms of cell injury. The nucleoplasm of many hepatic cells showed continuity with the cytoplasm due to loss of nuclear inner and outer membranes. Similar observation has been reported by Khangarot (1992) in Channa punctatus on exposure to copper.

Histopathological alterations in the renal tissues of treated mice in the present study showed renal toxicity of the arsenic. The shrinkage of glomeruli as observed in the present study may be due to capillary constriction because of arsenic concentration in the blood leading to decrease in glomerular filtration. The obliteration or reduction of tubular lumen may be due to edematous tubular cells. Cytoplasmic vacuolization with coarse pink granules and clumped chromatin or pycnotic nuclei indicates the severity of stress caused by arsenic. In agreement with the present results are those of Chishti and Rotkiewicz (1993) in cockerels and Garba et al. (2007) in rats who found that cadmium chloride and pyrethroid exposures respectively caused irregular foot processes in the renal corpuscles as well as thickening of glomerular basement membrane and marked ultra-structural changes in the proximal tubular cells. Pathological changes observed in the present study are severe enough to cause impairment in the functioning of the kidney. These degenerative changes may be due to altered metabolic activity or due to metal ion renal tissue interaction as suggested by Gupta and Rajbanshi $(1979,1982)$ and Sharma and Sharma (1994).

\section{ACKNOWLEDGEMENTS}

The authors wish to express their deep sense of gratitude to Prof. V. G. Jadhao, Principal for his constant encouragement and providing all facilities to carryout the study. We are thankful to Mr. Manoj Kumar, Laboratory Assistant, Zoology department for his untiring help.

\section{REFERENCES}

Adam H. and Caihak G. (1964). Grosses zoologisches parktikum tell. Arbeitsmethoden der makropischen anatomic Mit 283 Abbildungen Gustav. Fischer Verlag Stuttgart. Aronson, S.N.: Arsenic and old myths. R.I.MEd., 77:233234.

Aronson, S.N. (1994). Arsenic and old myths. R. I. M ed., 77: 233-234.

Babu, Sarath M., Venu Gopal, N. and Pratap Reddy, K. (2007). Post natal antioxidant enzyme activity of rat brain regions during developmental lead exposure. J. Environ. Biol., 28: 21-27.

Bataineh, H., Al-Hamood, M. and Elbetieha, A. (1998). Assessment of aggression, sexual behaviour and fertility in adult male rat following long-term ingestion of four industrial metal salts. J. H uman Exp. Toxicol., 17: 570-576.

Bench, G., M. H. R. Corzett, R. Martinelli and Balhorn (1999). Cadmium exposure in the testis, sperm and spermatids of mice subjected to long-term cadmium chloride exposure. J . Cytometry, 35: 30-36.

Butcher, R. W. (1946). The biological detection of pollution. J . Ind. Sew. Pur., (2): 92-97.

Chishti M.A. and Rotkiewicz, T. (1993). Hepatic and renal ultra-structural changes in cockerels exposed to cadmium chloride \& subsequent interaction with organophosphate insecticide. J . Environ. Pathol. Toxicol. O ncol., 12 (1): 3545.

Chougule, P., Patil, B. and Kanase, A. (2005). Lead nitrate induced unallied expression of liver and kidney functions in male albino rats. J . Envir on. Biol., 26: 421-424.

Dalwani, R., Dave, J. M. and Datta, K. (1985). Alterations in hepatic heme metabolism in fish exposed to sublethal cadmium level. Biochem. Int., 10 (1): 33-42.

Dinodia, G.S., Gupta, R.K. and Jain, K.L. (2002). Effect of cadmium toxicity on liver glycogen in some fresh water fishes. Proc. XI National Symp. Environ. 236-238.

Doreswamy, K., Balakrishna Shrilatha, Thimappa Rajesh Kumar and Muralidhara (2004). Nickel induced oxidative stress in testis of mice: Evidence of DNA damage and Genotoxic effects. J ournal of Andrology, 25, 6 November/ December .

Elbetieha, A. and Al-Hamood, M. (1997). term exposure of male and female mice to trivalent and hexavalent chromium compounds. Effect on fertility. J. Toxicol., 116: 39-47.

Favino, A., Baillie, A. and Griffiths, K. (1966). Androgen synthesis by the testes and adrenal glands of rat poisoned with cadmium chloride. . . E ndocrinol., 35:85-192.

Fengyuan Piao, Ning Ma, Yusukefliraku, Mariko Murata, Shinji Oikawa, Fanyin Cheng, Laifu Zhong, Toru Yamauchi, Shosuke Kawanishi and Kazuhito Yokoyama (2005). Oxidative DNA Damage in relation to Neurotoxicity in the 
Brain of Mice Exposed to Arsenic at Environmentally Relevant Level. J Occup H ealth, 47: 445-449.

Fiorini, C., Tilloy-Ellul, A., Chevalier, S., Charuel, C. and Pointis, G. (2004). Sertoli cell junctional proteins as early targets of different classes or reproductive toxicants. J. Reprod. Toxicol., 18: 413-421.

Foulkes, E. C. (1990). Biological effects of heavy metal.In: Metal carcinogenesis. Vol. II. CRC Press, Florida, USA.

Garba, S. H., Shehu, M. M and Adelaiya, A. B. (2007). Toxicological Effects of Inhaled Mosquito Coil Smoke on the Rat Spleen: A Haematological \& Histological study. J. Med. Sci., 7 (1): 94-99.

Gill, T. S. and Pant, J. C. (1987). Haematological and Pathological effects of chromium toxicosis in the freshwater fish Barbus conchonius Ham. Water Air Soil Poll. 35: 241250.

Gravin, A.J., Hall, B.J., Brissie, R.A., and Spicer, S.S. (1976). Cytochemical differentiation of nucleic acid with sciffmethylene blue sequence. J histochem. Cytochem, 24:587590

Gupta, A. K. and Rajbanshi, V. K. (1979) Histopathological changes resulting from bioassay copper to H eter opneustes fossils (Bloch). Proc. Symp. Environ. Biol., 167-172.

Gupta, A. K. and Rajbanshi, V. K. (1982). Cytopathological studies resulting in cadmium bioassay with $\mathrm{H}$ eter opneustes fossils (Bloch.). Acta H ydrochem. H ydrobiol., 10 (4): 345351.

Gupta, P. and Srivastava, N. (2006). Effect of sub-lethal concentrations of zinc on histological changes and bioaccumulation of zinc by kidney of fish Channa punctatus (Bloch). J ournal of Environmental Biology, 27 (2): 211-215.

Gurer Orhan, H. and Ercal, N. (2000). Can antioxidants are beneficial in the treatment of lead poising. F ree radical Biol. Med., 29: 927-945.

Kamble, G.B. and Muley, D.V. (2000). Effect of acute exposure of endosulfan and chlorpyriphos on the biochemical composition of the freshwater fish, Sarotherodon mossambicus. Indian J. Environ. Sci., 4(1): 97-102.

Karmakar, R., Bhattacharya, R. and Chatterjee, M. (2000). Biochemical, haematological and histopathological study in relation to time-related cadmium-induced hepatotoxicity in mice. Biometals, 13 (3): 231-239.

Khangarot BS. (1992). Copper induced hepatic ultrastructural alterations in the snake-headed fish, Channa punctatus. Ecotoxicol Environ Saf., 3(3):282-93.

Kwon, K.S., Cho, K.J. and Yang, E.J. (1997). The study of anatomical and biochemical effects of cadmium on the testis in rats. Dev. Reprod., 1: 125-132.

Mason, K., Brown, J., Young, J. and Nesbit, R. (1964). Cadmium induced injury of the rat testis. J . Analytical Res., 149: 135-148.

Mayyas, I., Elbetieha, A., Khamas, W. and Khamas, W. A. (2005). Evaluation of reproductive and fertility toxic potentials of aluminium chloride on adult male mice. J Anim. Vet. Adv., 4: 224-233.

McDowell, L.S. (1992). Minerals in Animal \& human nutrition. Academic Press Inc. California, 361-364.
Parizek, A., (1960). Sterilization of the male by cadmium salts. J. Reprod. Fertility, 1: 294-309.

Patlolla A. K. and Tchounwon, P. B. (2005). Cytogenetic evaluation of arsenic trioxide toxicity in Sprague-Dawley rats. Mutation Research/ Genetics Toxicology and Environmental M utagenesis, 587 (1-2): 126-133.

Robbins, S. and Angell, D. (1976). Basic Pathology, $2^{\text {nd }}$ Ed, W. B. Sauders Company, Philadlphia, London.

Roy, P. and Saha, A. (2002). Metabolism and toxicity of arsenic: A human carcinogen. Current Science, 82 (1): 38-45.

Saksena, S. and Lau, I. (1979). Effects of cadmium chloride on testicular steroidogenesis and fertility of male rats. J. Endocrinol,74: 6-12.

Saleha Banu, B., Danadevi, K., Jamil, K., Ahuja, Y. R., Visweswara Rao, K. and Ishaq, M. (2001). In vivo genotoxic effect of arsenic trioxide in mice using comet assay. Toxicology, 162(3):171-177.

Sharma, A. and Sharma, M. S. (1994). Toxic effect of zinc smelter effluent on some developmental stages of fresh water fish. Cyprinus carpio (Linnaeus). J. Environ. Biol., 15(3): 221-229.

Sharma, G. P., Sareen, M. L. and Monga, V. K. (1980). Effect of cadmium chloride on the testis of the Guinea - pig, Cavia cobaya. Proc. Nat. Agad. Sci. India, 50 (B), III.

Shukla, V., Rathi, P. and Sastry, K. V. (2002). Effect of cadmium individually and in combination with other metals on the nutritive value of fresh water fish, Channa punctatus. J. Environ. Biol., 23 (2): 105-112.

Soni, A. and Gupta, A.K. (2006). Toxic effects of mercuric chloride and influence of EDTA on the gills of $\mathrm{H}$ eter opneustes fossilis (Bloch.). In Press.

Srivastava, N. and Kaushik, N. (2001). Use of fish as bioindicator of aquatic pollution. In: Abstracts presented at International congress of Chemistry and environment. $16^{\text {th }}$ - $18^{\text {th }}$ Dec., 2001, Indore, India.

Srivastava, N. and Sharma, R. (1996). Toxicity of zinc in fish Channa punctatus (Bloch.) as influenced by temperature and $\mathrm{pH}$ of water. Indian J. Anim. Nutr., 13(2): 87-90.

Stinson, T.J., Jaw, S., Jeffery, E.H., Plewa, M.J. (1992). The relationship between nickel chloride-induced peroxidation and DNA strand breakage in rat liver. Toxicol Appl Pharmacol, 117:98-103.

Tbeileh, N. Ahmed Elbetieha, Homa Darmani and Wael Khamas (2007). Effects of Long Term Exposure to Cadmium Chloride on Fertility in Adult Male Mice. Veterinar y Research, 1(2): 40-48.

Valverde, M., Teresa I. Fortoul, Fernando Diaz-Barriga, Jesus Mejia and Emilio Rojas Del Castillo (2002). Genotoxicity induced in CD-1 mice by inhaled lead: differential organ response. M utagenesis, 17(1): 55-61.

Yang. H. S. Dong Kein Han, Jung Ran Kim and Jae Chul Sim (2006). Effects of a-tocopherol on cadmium induced toxicity in Rat Testis and Spermatogenesis. J ournal of K orean M edical Science, 21(3): 445-451.

Zhang L.Y. and Wang, C.X. (1984). Histopathological and histochemical studies on toxic effect of brodifacoum in mouse liver. Acta Acad M ed Sci., 6(5):386-388. 